\title{
Zoom Cloud Meeting: Media Alternatif dalam Pembelajaran Maharah Kalam di Tengah Wabah Virus Corona (Covid-19)
}

\author{
Mahfuz Rizqi Mubarak \\ Institut Agama Islam Negeri Palangka Raya \\ mahfuzrizqimubarak@iain-palangkaraya.ac.id \\ Nurul Wahdah \\ Institut Agama Islam Negeri Palangka Raya \\ Nwahdah1980@gmail.com \\ Aulia Mustika Ilmiani \\ Institut Agama Islam Negeri Palangka Raya \\ Aulia.mustika.ilmiani@iain-palangkaraya.ac.id \\ Hamidah \\ Institut Agama Islam Negeri Palangka Raya \\ hamidah@iain-palangkaraya.ac.id
}

\begin{abstract}
This paper explores the stages of speaking skill's online lectures using the Zoom Cloud Meeting media as well as the advantages and disadvantages of the Zoom Cloud Meeting media. This study used a descriptive qualitative approach with three data collection techniques, namely observation, interviews, and documentation. The results showed that there were several stages used by lecturers in the implementation of speaking skill lectures using Zoom Cloud Meeting media, namely: (1) PreLecture, (2), Lecture Implementation, (3) and Class Evaluation. There are several features of the Zoom Cloud Meeting media used by lecturers in the implementation of speaking skill lectures such as Schedule, mute \& unmute, record, chat, and whiteboards. Researchers also found several advantages regarding the implementation of speaking skill lectures using Zoom Cloud Meeting media such as flexibility in the lecture process, increasing discipline for lecturers and students, and several additional features that can support the smooth implementation of lectures. However, the implementation of lectures using this media is also inseparable from shortcomings such as a poor internet network and limited duration of the free Zoom Cloud Meeting media which can only be used for 40 minutes. From the results of this study, it is hoped that it can provide alternative solutions for lecturers in dealing with online lectures in the midst of the COVID-19 pandemic.
\end{abstract}

Keywords: Covid 19, speaking skill, zoom 


\begin{abstract}
Abstrak
Tulisan ini mengeksplorasi tahapan-tahapan perkuliahan Maharah Kalam secara daring (online) dengan menggunakan media Zoom Cloud Meeting serta kelebihan dan kekurangan dari media Zoom Cloud Meeting tersebut. Penelitian ini menggunakan pendekatan kualitatif deskriptif dengan tiga teknik pengumpulan data yaitu observasi, wawancara, dan dokumentasi. Hasil penelitian menunjukkan bahwa ada beberapa tahapan yang digunakan dosen dalam pelaksanaan perkuliahan Maharah Kalam menggunakan media Zoom Cloud Meeting, yakni: (1) Pra-Perkuliahan, (2), Pelaksanaan Perkuliahan, (3) dan Evaluasi Perkuliahan. Ada beberapa fitur dari media Zoom Cloud Meeting yang digunakan Dosen dalam pelaksanaan perkuliahan Maharah Kalam seperti Schedule, mute \& unmute, record, chat, dan whiteboard. Peneliti juga menemukan beberapa kelebihan mengenai pelaksanaan perkuliahan Maharah Kalam menggunakan media Zoom Cloud Meeting seperti fleksibilitas dalam proses perkuliahan, meningkatkan kedisiplinan dosen dan mahasiswa, dan beberapa fitur tambahan yang dapat menunjang kelancaran pelaksanaan perkuliahan. Namun, pelaksanaan perkuliahan dengan menggunakan media ini juga tidak lepas dari kekurangan seperti jaringan internet yang kurang baik dan pembatasan durasi dari media Zoom Cloud Meeting gratis yang hanya dapat digunakan Selama 40 menit. Dari hasil penelitian ini, diharapkan dapat memberikan solusi alternatif terhadap Dosen dalam menghadapi perkuliahan secara daring (online) di tengah pandemi wabah covid19.
\end{abstract}

Kata Kunci: Covid 19, maharah kalam, zoom

\title{
Pendahuluan
}

Saat ini dunia digemparkan dengan penyebaran wabah virus Covid-19 atau yang populer dengan istilah Corona Virus Disease. Fenomena pandemi virus ini mengharuskan beberapa Negara seperti China, Filipina, Iran, Italia, Denmark, dan Spanyol mengambil kebijakan lockdown untuk mengantisipasi penyebaran virus Corona ${ }^{1}$. Kebijakan lockdown pada sebuah Negara mengarah kepada penutupan semua fasilitas publik yang ada di Negara tersebut. Perguruan Tinggi, Sekolah, Transportasi Umum, Tempat Umum, Perkantoran, bahkan pabrik harus ditutup dan tidak diperkenankan untuk beraktivitas ${ }^{2}$.

Adapun di Indonesia, jumlah pasien virus Corona sampai tanggal 24 Maret 2020 telah mencapai sebanyak 686 kasus dan diprediksi akan terus meningkat mengingat masih belum ditemukannya obat untuk mengakhiri penularan virus Corona. Hal ini tentunya membuat kekhawatiran terhadap

${ }^{1}$ Rehia Sebayang, "Pasien Covid-19 RI 117 Orang, Jokowi Bicara Soal Lockdown," news, accessed November 11, 2020, https://www.cnbcindonesia.com/news/20200315154622-4144982/pasien-covid-19-ri-117-orang-jokowi-bicara-soal-lockdown.

2 Karwati Putu Latief, "Arti Lockdown, Social Distancing dan Istilah Populer Seputar Virus Corona," Harapan Rakyat Online (blog), March 15, 2020, https://www.harapanrakyat.com/2020/03/arti-lockdown-social-distancing-dan-istilah-populerseputar-virus-corona/. 
masyarakat Indonesia. Presiden telah menginstruksikan untuk melakukan pekerjaan di rumah, belajar di rumah, dan melaksanakan ibadah di rumah ${ }^{3}$. Prof. Ir. Nizam, M.Sc selaku Plt Dirjen Dikti juga menambahkan bahwa untuk pelaksanaan pembelajaran sebaiknya dilakukan secara Online untuk menghindari kontak langsung yang berimplikasi pada penyebar luasan virus ${ }^{4}$.

Menindaklanjuti himbauan tersebut, Direktur Jenderal Pendidikan Islam menginstruksikan seluruh Rektor PTKI di seluruh Indonesia yang tertuang dalam surat edaran Nomor: 697/03/2020 bahwa proses perkuliahan hingga akhir semester genap tahun akademik 2019/2020 sepenuhnya dilakukan secara daring (Online). Hal ini dilakukan sebagai upaya pencegahannya penyebaran Covid-19 (Corona) di lingkungan PTKI.

Perkuliahan secara daring (online) ini tentunya menimbulkan pro dan kontra baik dari kalangan dosen maupun mahasiswa. Berdasarkan observasi dan wawancara peneliti terhadap beberapa dosen dan mahasiswa di IAIN Palangka Raya, sebagian mereka memberikan tanggapan positif bahwa perkuliahan secara daring dapat mengantisipasi terjadinya kontak langsung antara dosen dan mahasiswa yang berimplikasi terjadinya penularan covid-19. Beberapa mahasiswa juga beranggapan bahwa pembelajaran secara daring memberikan kemudahan kepada mereka untuk mengikuti perkuliahan di manapun dan kapanpun.

Namun, beberapa Dosen tertentu cenderung mengalami kesulitan dalam pelaksanaan perkuliahan secara online. Beberapa dari mereka masih belum terbiasa dengan perkembangan teknologi atau yang lebih dikenal dengan istilah gaptek (gagap teknologi). Beberapa Dosen lainnya juga mengalami masalah pada pemilihan media mengingat beberapa mata kuliah yang diajarkan mengharuskan terjadinya proses tatap muka (face to face) secara langsung seperti mata kuliah Maharah Kalam dalam pembelajaran bahasa Arab. Mereka berasumsi bahwa keobjektifan hasil kemampuan Kalam mahasiswa hanya bisa dilihat dari proses komunikasi face to face secara langsung baik antara mahasiswa dengan dosen maupun antar mahasiswa. Peneliti juga sependapat dengan asumsi tersebut mengingat hasil penelitian dari penelitian sebelumnya mengungkapkan bahwa hasil pembelajaran Maharah Kalam yang diselenggarakan tanpa melibatkan

\footnotetext{
3 "Instruksi Presiden Jokowi: Saatnya Kerja dari Rumah, Belajar dari Rumah, Ibadah di Rumah," Serambi Indonesia, accessed November 11, 2020, https://aceh.tribunnews.com/2020/03/15/instruksi-presiden-jokowi-saatnya-kerja-dari-rumahbelajar-dari-rumah-ibadah-di-rumah.

${ }^{4}$ Liputan6.com, "Antisipasi Covid-19, Dikti Minta Kampus Selenggarakan Kuliah Jarak Jauh,” liputan6.com, March 2020, https://www.liputan6.com/news/read/4201640/antisipasi-covid-19-dikti-minta-kampusselenggarakan-kuliah-jarak-jauh.
} 
komunikasi face to face rentan mengalami kecurangan seperti membaca teks/naskah dibalik layar sehingga hasil yang didapat tidak objektif.'

Maka dari itu, diperlukan adanya sebuah solusi berbentuk media penunjang perkuliahan secara online yang mudah dan representatif untuk semua mata kuliah di PTKI khususnya mata kuliah yang mengharuskan adanya komunikasi face to face secara langsung seperti mata kuliah Maharah Kalam.

Salah satu Dosen di IAIN Palangka Raya memberikan solusi dengan merekomendasikan media Zoom Cloud Meeting dalam pelaksanaan perkuliahan Maharah Kalam di masa pandemi covid-19. Dari hasil wawancara, Dosen tersebut mengungkapkan bahwa media Zoom Cloud Meeting cukup representatif digunakan dalam perkuliahan Maharah Kalam. Fitur meeting online yang disediakan oleh media ini dapat memungkinkan terlaksananya perkuliahan secara face to face meskipun tidak berada di satu tempat. Dosen tersebut juga menambahkan bahwa aktivitas Face to face sangat diperlukan dalam perkuliahan Mabarah Kalam.

Maka dari itu, peneliti tertarik untuk mengeksplorasi lebih dalam mengenai proses perkuliahan Maharah Kalam menggunakan media Zoom Cloud Meeting di masa pandemi covid-19. Peneliti berharap bahwa hasil penelitian ini akan memberikan solusi berupa wawasan kepada para Dosen khususnya pengampu mata kuliah Maharah Kalam di tingkat Perguruan Tinggi tentang proses perkuliahan Mabarah Kalam menggunakan aplikasi Zoom Cloud Meeting.

Berikut beberapa hasil penelitian terdahulu yang telah terpublikasi di skala internasional mengenai penggunaan media Zoom Cloud Meeting yakni: Archibald, dkk mengungkapkan bahwa media Zoom Cloud Meetings menawarkan peluang baru untuk melakukan wawancara dalam penelitian kualitatif (Qualitative Research). Dari 16 responden yang berpartisipasi pada wawancara menggunakan media Zoom Cloud Meetings memberikan nilai yang sangat positif dan bahkan merekomendasikan media tersebut dibandingkan dengan media-media Meetings lainnya ${ }^{6}$.

Hiong, dkk dalam penelitiannya mengungkapkan bahwa kegiatan pembelajaran dengan pendekatan Blended Learning menggunakan media Zoom Cloud Meeting mampu memberikan respon positif terhadap dosen di salah satu Perguruan Tinggi di Malaysia. dosen dapat melaksanakan kegiatan pembelajaran secara face to face di manapun dan kapanpun sehingga tidak mengurangi keaktifan interaksi antara dosen dengan mahasiswa. Dengan media ini, dosen lebih

${ }^{5}$ Mahfuz Rizqi Mubarak et al., "Penggunaan Vlog Dalam Pembelajaran Mahārah Kalām," Al Mi'yar: Jurnal Ilmiah Pembelajaran Bahasa Arab dan Kebahasaaraban 3, no. 1 (April 4, 2020): 109_ 26, https://doi.org/10.35931/am.v3i1.209.

${ }^{6}$ Mandy M. Archibald et al., "Using Zoom Videoconferencing for Qualitative Data Collection: Perceptions and Experiences of Researchers and Participants:," International Journal of Qualitative Methods, September 11, 2019, https://doi.org/10.1177/1609406919874596. 
terbuka untuk menerima hal-hal yang baru dan sangat bersedia untuk menjelajahinya "More open to new tools, more willing to explore them"?

Terakhir, Sutterlin dalam penelitiannya menambahkan bahwa dengan media Zoom Cloud Meeting tidak ada lagi pengajar yang membatalkan pertemuan karena cuaca buruk, bahkan siswa yang sakit pun tetap dapat menghadiri kelas dan tidak akan khawatir ketinggalan pelajaran ${ }^{8}$. Bahkan dalam penelitian lainnya siswa cenderung tidak setuju jika seorang Pengajar harus hadir secara fisik dalam proses pembelajaran karena tidak ada perbedaan yang signifikan antara komunikasi secara virtual maupun secara langsung bahkan lebih ideal dengan menggunakan komunikasi secara virtual yang tersedia di media Zoom Cloud Meeting.

Pada penelitian ini, peneliti menggunakan pendekatan kualitatif deskriptif untuk mengeksplorasi proses perkuliahan Maharah Kalam dengan menggunakan media Zoom Cloud Meeting untuk mahasiswa program studi Pendidikan Bahasa Arab IAIN Palangka Raya. Penelitian ini menggunakan tiga Teknik pengumpulan data yakni, observasi, wawancara, dan dokumentasi. Observasi dilakukan untuk mengeksplorasi langkah-langkah penggunaan media Zoom Cloud Meeting dalam perkuliahan Maharah Kalam di masa pandemi covid-19. Ada beberapa pihak yang peneliti wawancarai yakni dosen pengampu mata kuliah Maharah Kalam dan mahasiswa prodi PBA IAIN Palangka Raya sebagai informan penelitian. Adapun Dokumentasi dari penelitian ini berupa photo saat proses perkuliahan Maharah Kalam menggunakan media Zoom Cloud Meeting berlangsung.

\section{Hasil dan Pembahasan}

Beberapa data yang peneliti kumpulkan dari proses observasi, wawancara, dan dokumentasi pada proses perkuliahan Maharah Kalam menggunakan aplikasi Zoom Cloud Meeting di masa pandemi covid-19, peneliti merumuskan beberapa tahapan yakni:

\section{Pra-Perkuliahan}

Dosen terlebih dahulu mengkomunikasikan tema materi yang akan digunakan pada perkuliahan menggunakan media Whatsapp atau media sosial

${ }^{7}$ Siaw Nyuk Hiong et al., "A SWOT-Thematic Analysis of Blended Learning Practices at Institute of Teacher Education Malaysia," DEStech Transactions on Social Science, Education and Human Science 0, no. ICEdDE (2019), https://doi.org/10.12783/dtssehs/ICEdDE2019/33702.

8 Jane Sutterlin, "Learning Is Social with Zoom Video Conferencing in Your Classroom," ELearn 2018, no. 12 (December 28, 2018): 5, https://doi.org/10.1145/3302261.3236697.

9 Amber Y. Darr et al., "Design and Students' Perceptions of a Virtually Facilitated Outpatient Pharmacy Practice Laboratory Course," Currents in Pharmacy Teaching and Learning 11, no. 7 (July 1, 2019): 729-35, https://doi.org/10.1016/j.cptl.2019.03.012. 
lainnya yang dapat dijangkau oleh mahasiswa seminggu sebelum perkuliahan. Tema yang akan digunakan pada perkuliahan Maharah Kalam ini adalah الخبرة الرائعة (Pengalaman yang luar biasa). dosen juga menjelaskan tujuan yang akan dicapai pada tema mata kuliah tersebut. Tujuan yang akan dicapai pada tema ini adalah "mahasiswa mampu berkomunikasi dan bercerita secara lisan menggunakan bahasa Arab tentang pengalaman luar biasa yang terjadi pada mahasiswa".

Dosen mempersilahkan mahasiswa untuk aktif mencari sumber belajar yang dapat dijadikan acuan dalam berkomunikasi dan bercerita menggunakan bahasa Arab seperti al-Muhawarah al-Haditsah karangan Habib Hasan bin Ahmad Baharun, al-Arabiyyah Bayna Yadaik karangan Abdurrahman bin Ibrahim AlFauzan, al-Qiraatul al-Rasyidah karangan Abdul Fatah Shabri dan Kamus Ma'aniy yang tersedia secara online pada link berikut https:///www.almaany.com.

Dosen memberikan kebebasan terhadap mahasiswa untuk menghafal isi secara keseluruhan atau hanya cukup menghafal model cerita atau dialog yang disajikan di dalam sumber belajar.

Dosen juga menginstruksikan kepada mahasiswa untuk mengunduh dan menginstal terlebih dahulu media Zoom Cloud Meeting yang tersedia di PC/Laptop, dan Smartphone yang sudah beroperasi menggunakan teknologi Android maupun IOS.

Gambar 1. Ikon media Zoom Cloud Meeting

\section{Pelaksanaan Perkuliahan}

Pada pelaksanaan perkuliahan, dosen terlebih dahulu mengoperasikan media Zoom Cloud Meeting dan mendistribusikan link URL server New Meeting ke seluruh mahasiswa. Setelah didistribusikan, dosen memastikan bahwa seluruh mahasiswa telah bergabung pada server Meeting dengan melakukan pengabsenan satu persatu pada mahasiswa. dosen juga menyalakan fitur record untuk merekam proses berjalannya perkuliahan. 


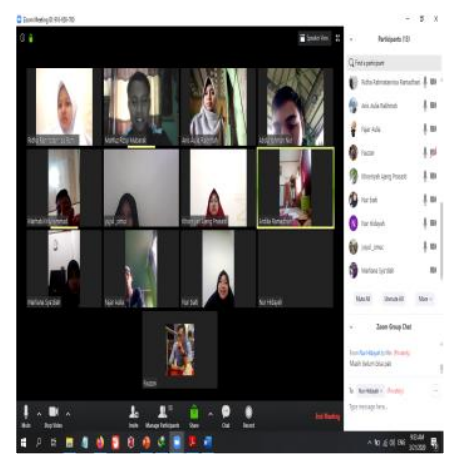

Gambar 2. Ikon fitur record pada media Zoom Cloud Meeting

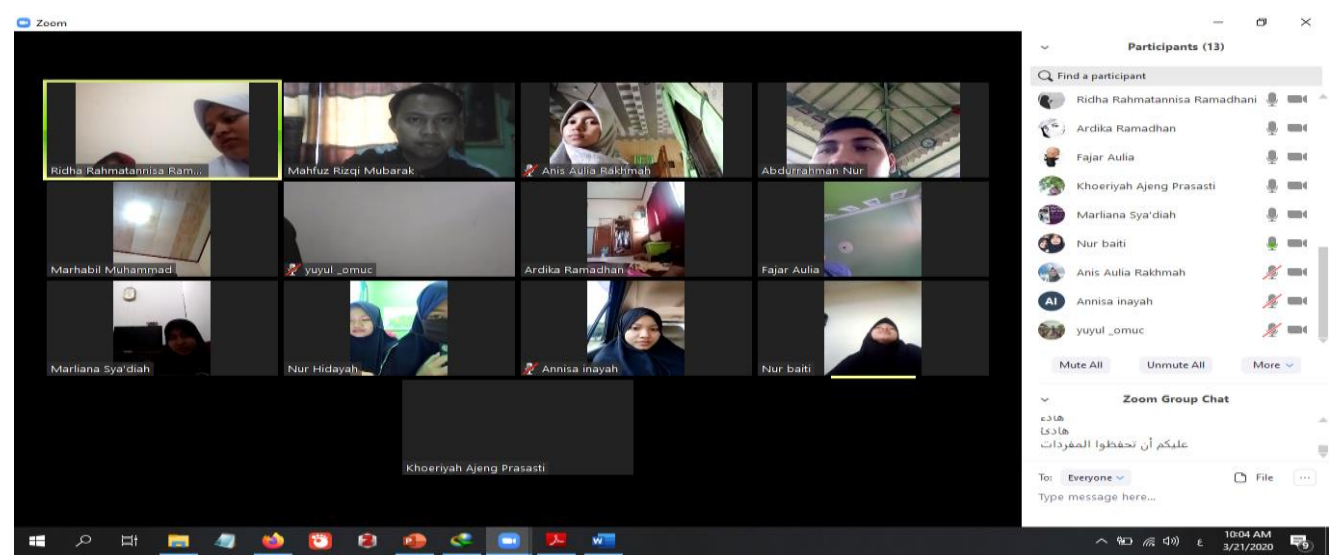

Gambar 3. Proses perkuliahan Maharah Kalam menggunakan media Zoom Cloud

\section{Meeting}

Dalam pelaksanaannya, dosen menggabungkan dua metode yaitu storytelling dan mubadatsah. Storytelling digunakan dengan mempersilahkan salah satu mahasiswa untuk bercerita tentang الخبرة الرائعة yang pernah dia alami selama 10 menit. dosen meminta kepada seluruh mahasiswa yang tergabung di media Zoom Cloud Meeting untuk menyimak cerita yang akan diperdengarkan oleh mahasiswa yang akan bercerita. Pada saat salah satu mahasiswa bercerita, dosen memanfaatkan fitur "mute" yang tersedia pada media untuk mematikan speaker mahasiswa lainnya. Fitur mute ini mempermudah para mahasiswa untuk mendengarkan secara seksama apa yang diceritakan oleh mahasiswa yang sedang bercerita. Hal ini juga membantu dosen tersebut untuk memberikan penilaian hasil cerita yang disampaikan secara lisan sesuai standar penilaian yang pada perkuliahan Mabarab Kalam. 


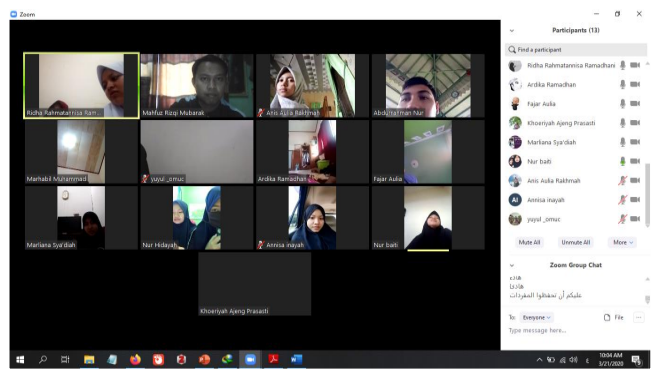

Gambar 4. Penggunaan fitur unmute yang tersedia di media Zoom Cloud Meeting

Setelah mahasiswa menyelesaikan cerita tentang الخبرة الرائعة, dosen menggunakan metode kedua yaitu metode Mubadatsah. dosen terlebih dahulu mematikan fitur "mute" dengan menggunakan fitur "unmute" lalu mempersilahkan mahasiswa lainnya untuk memulai pertanyaan berkaitan dengan hasil cerita yang telah disampaikan sebelumnya. dosen membatasi sebanyak lima pertanyaan per sesi. dosen mengungkapkan bahwa proses Muhadatsah ini bermanfaat untuk melihat sejauh mana perhatian mahasiswa terhadap cerita yang disampaikan. Hal ini sangat diperlukan untuk meminimalisir kurangnya perhatian mahasiswa ketika proses pembelajaran mengingat para mahasiswa yang berpartisipasi pada proses pembelajaran secara daring (online) tidak berada di satu ruangan (kelas) melainkan di rumah atau asrama mereka masing-masing.

Dosen juga memanfaatkan fitur chat jika dalam proses penggunaan metode Storytelling dan Muhadatsah ada beberapa mahasiswa yang mengalami kerusakan pada speaker sehingga berakibat pada tidak terdengarnya beberapa kata atau ungkapan.

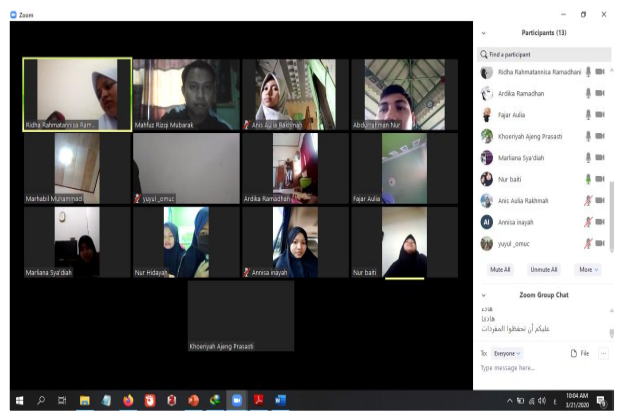

Gambar 5. Fitur Chat

Dosen menerapkan tahapan-tahapan pada penggunaan metode storytelling sampai mubadatsah sebanyak 3 atau 4 kali dalam satu pertemuan sesuai dengan kebutuhan dan jumlah dari banyaknya partisipan mahasiswa yang mengikuti perkuliahan Maharah Kalam dengan menggunakan media Zoom Cloud Meeting.

\section{Evaluasi Perkuliahan}


Menjelang akhir Perkuliahan, dosen melakukan refleksi hasil perkuliahan yang telah dilakukan dari awal sampai akhir selama lima menit. Dalam perkuliahan Mabarab Kalam, dosen menilai beberapa aspek yang dinilai seperti pelafalan/suara, tata bahasa, pemilihan kosakata (Mufradath), kelancaran, dan kemampuan merespon pertanyaan dengan baik dari para mahasiswa selama proses perkuliahan berlangsung. dosen juga memanfaatkan fitur Whiteboard untuk membantu jalannya proses refleksi hasil perkuliahan.

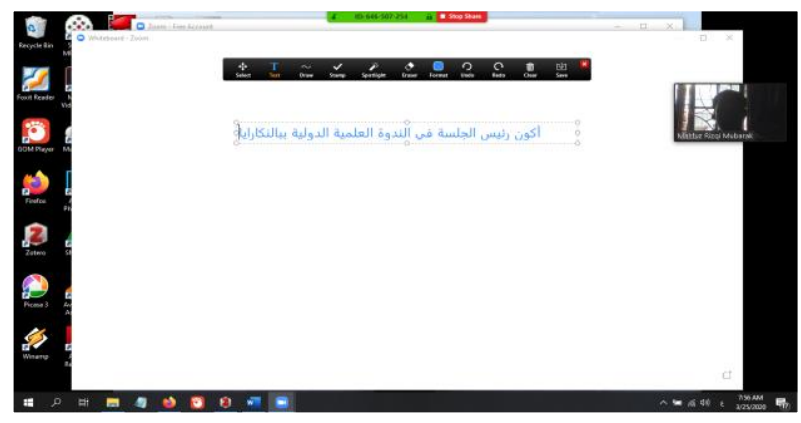

Gambar 6. Fitur Whiteboard

Pembelajaran secara daring (online) atau E-Learning merupakan implikasi hasil yang positif dari perkembangan teknologi internet di era Revolusi Industri 4.0. Hadirnya internet memberikan manfaat kepada masyarakat untuk menggali berbagai macam informasi serta ilmu pengetahuan yang tersebar luas di dunia maya seperti website ${ }^{10}$ maupun media sosial (facebook ${ }^{11}$, YouTube ${ }^{12}$, dan Instagram) serta memanfaatkannya sebagai media alternatif pembelajaran ${ }^{13}$.

Lahirnya internet menghadirkan fleksibilitas dalam proses belajar mengajar. Kegiatan belajar mengajar yang umumnya dilakukan di kelas sekarang dapat dilakukan di manapun dan kapanpun ${ }^{14}$. Tentunya hal ini memberikan tuntutan para Pendidik untuk berinovasi dalam mengembangkan sebuah kegiatan Pembelajaran yang interaktif dan mampu meningkatkan motivasi

${ }^{10}$ Mohammad Taufiq Abdul Ghania, "The Effectiveness of Using Website in Learning Arabic Language for The Purpose of Tourism: A Case Study among Students at College PolyTech," International Conference on E-Learning, 2015, 9.

11 Rahmat Linur and Mahfuz Rizqi Mubarak, "Facebook Sebagai Alternatif Media Pengembangan Mahara Kitabah," Jurnal Naskbi: Jurnal Kajian Pendidikan Dan Babasa Arab 2, no. 1 (April 27, 2020): 8-18, https://doi.org/10.47435/naskhi.v2i1.154.

12 Aulia Mustika Ilmiani et al., "Multimedia Interaktif Untuk Mengatasi Problematika Pembelajaran Bahasa Arab," Al-Ta'rib: Jurnal Ilmiah Program Studi Pendidikan Bahasa Arab LAIN Palangka Raya 8, no. 1 (June 24, 2020): 17-32, https://doi.org/10.23971/altarib.v8i1.1902.

13 Azkia Muharom Albantani, "Social Media as Alternative Media for Arabic Teaching in Digital Era," ALSINATUNA 4, no. 2 (June 25, 2019): 148-61, https://doi.org/10.28918/alsinatuna.v4i2.2043.

${ }^{14}$ Haniah Haniah, "Pemanfaatan Teknologi Informasi Dalam Mengatasi Masalah Belajar Bahasa Arab," Al-Ta'rib: Jurnal Imiah Program Studi Pendidikan Bahasa Arab LAIN Palangka Raya 2, no. 1 (June 1, 2014), https://doi.org/10.23971/altarib.v2i1.588. 
belajar para Peserta Didik, mengingat kurangnya motivasi dan minat menjadi salah satu faktor kegagalan dari proses pembelajaran ${ }^{15}$. di sisi lain, kasus penyebaran wabah virus Corona yang terjadi di dunia juga menjadi salah satu alasan yang sangat fundamental bagi para Pendidik untuk menyelenggarakan kegiatan pembelajaran secara daring (online) tanpa menyampingkan interaksi face to face antara Pendidik dan Peserta Didik.

Dari hasil penelitian yang telah dilakukan, diketahui bahwa ada beberapa tahapan yang digunakan selama perkuliahan Maharah Kalam menggunakan media Zoom Cloud Meeting yakni: (1) Pra-Perkuliahan, (2) Pelaksanaan Perkuliahan, dan (3) Evaluasi Perkuliahan.

Pada tahapan pra-perkuliahan, ada beberapa hal yang ditekankan dosen pengampu mata kuliah Maharah Kalam sebelum perkuliahan berlangsung. Pertama, menjelaskan tujuan yang akan dicapai dari pelaksanaan perkuliahan tersebut. Pengetahuan tentang tujuan yang akan dicapai merupakan hal yang penting. Hal ini berimplikasi pada motivasi seorang pembelajar untuk mencapai hal yang akan dicapai dari proses pembelajaran tersebut. Tercapainya tujuan pembelajaran menjadi indikasi utama apakah proses pembelajaran tersebut efektif $^{16}$. Kedua, keaktifan mahasiswa untuk mencari sumber belajar secara mandiri sebelum perkuliahan dimulai juga menjadi hal yang penting dilakukan. Sumber belajar yang dimaksud adalah sumber yang berkaitan dengan tutorial penggunaan media Zoom Cloud Meeting dan sumber tentang perkuliahan Mabarah Kalam. Kemandirian untuk aktif mencari sumber belajar akan berpengaruh kepada kepercayaan diri mahasiswa dan juga membantu meminimalisir terjadinya ketidakpahaman saat proses perkuliahan berlangsung ${ }^{17}$. Ketiga, dosen memberikan kebebasan kepada mahasiswa untuk memilih antara menghafal isi secara keseluruhan atau hanya sebatas menghafal pola cerita atau dialog yang disajikan di dalam sumber belajar.

Pada tahapan pelaksanaan perkuliahan, dosen pengampu mengkombinasikan dua metode yaitu Storytelling dan mubadatsah. Peneliti menganggap bahwa kombinasi kedua strategi ini sangat representatif dalam pelaksanaan perkuliahan Maharah Kalam. Storytelling terbukti meningkatkan kreatifitas dan daya Tarik mahasiswa dalam perkuliahan Mabarah kalam ${ }^{18}$. Begitu

15 Rahmat Iswanto, "Pembelajaran Bahasa Arab dengan Pemanfaatan Teknologi," Arabiyatuna: Jurnal Babasa Arab 1, no. 2 (December 29, 2017): 139-52, https://doi.org/10.29240/jba.v1i2.286.

16 Amna Emda, "Kedudukan Motivasi Belajar Siswa dalam Pembelajaran," Lantanida Journal 5, no. 2 (March 15, 2018): 172-82, https://doi.org/10.22373/li.v5i2.2838.

17 Tsuwaybah Al Aslamiyah, Punaji Setyosari, and Henry Praherdhiono, "Blended Learning Dan Kemandirian Belajar Mahasiswa Teknologi Pendidikan," Jurnal Kajian Teknologi Pendidikan 2, no. 2 (June 22, 2019): 109-14, https://doi.org/10.17977/um038v2i22019p109.

18 Minatul Azmi and Maulida Puspita, "Metode Storytelling Sebagai Solusi Pembelajaran Maharah Kalam di PKPBA UIN Malang” 3, no. 0 (2019): 69-86. 
juga metode mubadatsah berimplikasi pada peningkatan penguasaan Kalam mahasiswa dengan memahami atau menangkap simbol-simbol bahasa Arab yang mereka peroleh secara langsung dari pembicara kedua ${ }^{19}$.

Pada tahapan evaluasi perkuliahan, dosen memanfaatkan fitur whiteboard yang disediakan oleh media Zoom Cloud Meeting untuk membantu jalannya proses refleksi hasil perkuliahan. Whiteboard memiliki fungsi yang sama seperti papan tulis yang ada di dalam kelas. Namun, whiteboard memiliki keunggulan seperti kemampuan untuk menampilkan PPT, artikel dalam bentuk PDF, dan lain sebagainya dikarenakan fitur ini adalah papan tulis virtual ${ }^{20}$.

\section{Kelebihan dan Kekurangan dari Penggunaan Media Zoom Cloud Meeting}

Peneliti menyimpulkan beberapa kejadian berdasakan hasil observasi peneliti dan beberapa tanggapan mahasiswa melalui wawancara mengenai pengalaman mereka menggunakan media Zoom Cloud Meeting dalam perkuliahan Maharah Kalam. Beberapa hasil tanggapan ini akan diklasifikasikan menjadi tanggapan positif dan negatif yang kemudian dituangkan pada aspek kelebihan dan kekurangan dari penggunaan media Zoom Cloud Meeting.

\section{Kelebihan}

1. Fleksibel

Sebagaimana yang telah disebutkan sebelumnya bahwa media ini menawarkan fleksibilitas dalam proses kegiatan perkuliahan. Baik dosen maupun Mahasiswa dapat mengatur waktu perkuliahan sesuai kesepakatan. Mahasiswa beranggapan bahwa kesepakatan waktu belajar adalah yang terpenting mengingat beberapa mahasiswa juga bekerja part-time di beberapa perusahaan seperti Gojek, Grab, dan di beberapa Lembaga Pendidikan sehingga diperlukan penyesuaian waktu antara bekerja dan kuliah.

Mahasiswa juga beranggapan bahwa fleksibilitas pembelajaran face to face merebaknya wabah virus corona yang mengharuskan adanya social distancing (pembatasan interaksi) antar masyarakat. Beberapa mahasiswa yang memutuskan untuk pulang ke kampung halaman juga merasa tidak khawatir ketinggalan perkuliahan selama kampung halaman mereka masih menyediakan akses internet.

2. Menyediakan Beberapa Fitur yang Menunjang Proses Perkuliahan

Adanya beberapa fitur tambahan seperti mute \& unmute, chat, record, dan whiteboard dapat menunjang proses berlangsungnya kegiatan perkuliahan. Ketika

19 Wa Muna Wa Muna, "Efektifitas Metode Muhadatsah Terhadap Penguasaan Bahasa Arab Mahasiswa STAIN Kendari," Shautut Tarbiyab 16, no. 1 (May 1, 2010): 108-19, https://doi.org/10.31332/str.v16i1.122.

20 “Zoom Meetings - Zoom," accessed October 18, 2020, https:// zoom.us/meetings. 
dosen menggunakan fitur mute pada saat salah satu mahasiswa bercerita, mahasiswa yang lain dapat mendengarkan dengan seksama cerita yang disampaikan tanpa adanya intervensi dari suara luar.

Fitur chat dan whiteboard juga sangat membantu mahasiswa dalam memahami beberapa ungkapan yang tidak terdengar dengan baik disebabkan naik turunnya sinyal jaringan internet atau adanya gangguan kerusakan pada speaker yang ada pada laptop atau smart phone mereka.

Fitur Record digunakan untuk merekam proses berlangsungnya kegiatan perkuliahan dari awal sampai akhir dalam bentuk video. Hasil rekaman video dapat membantu dosen untuk mengevaluasi hasil seluruh proses kegiatan perkuliahan yang telah berlangsung. Mahasiswa juga dapat menggunakan hasil rekaman video tersebut untuk mengulangi hasil evaluasi dari apa yang telah disampaikan oleh dosen pada akhir perkuliahan.

3. Meningkatkan Kedisiplinan Dosen dan Mahasiswa

Fleksibilitas yang diberikan oleh media Zoom Cloud Meeting tentunya juga memberikan dampak positif pada kedisiplinan dosen maupun mahasiswa. Jadwal perkuliahan yang telah disepakati antara dosen dan mahasiswa menuntut lahirnya komitmen dan tanggung jawab dari kedua belah pihak untuk saling menepati apa yang telah disepakati kecuali bila ada kejadian atau alasan yang dapat diterima dan masuk akal.

\section{Kekurangan}

1. Jaringan Internet yang Kurang Baik

Jaringan internet yang kurang baik selalu menjadi salah satu kendala yang terjadi dalam pelaksanaan perkuliahan secara daring (online). Hal ini juga terjadi di beberapa kampus ternama seperti pelaksanaan perkuliahan bahasa Arab melalui Google Classroom di UIN Syarif Hidayatullah Jakarta ${ }^{21}$ dan pembelajaran Maharah Kalam melalui grup Whatsapp di PKPBA UIN Maliki Malang22. Dalam pelaksanaan perkuliahan Maharah Kalam dengan menggunakan Zoom Cloud Metiing ini juga mengalami kendala yang sama pada jaringan internet. mahasiswa yang mengandalkan jaringan internet pada smartphone sering mengalami kendala seperti suara dengan video yang tidak singkron atau bahkan suara atau video tersebut menghilang sehingga cerita yang sampaikan oleh mahasiswa tidak dapat dijangkau.

${ }^{21}$ Abd Rozak and Azkia Muharom Albantani, "Desain Perkuliahan Bahasa Arab melalui Google Classroom," Arabiyat: Jurnal Pendidikan Bahasa Arab dan Kebabasaaraban 5, no. 1 (June 3, 2018): 83-102, https://doi.org/10.15408/a.v5i1.7481.

22 Halimatus Sa diyah, "Upaya Menumbuhkan Self-Confidence Berbicara Bahasa Arab Mahasiswa Melalui Grup Whatsapp," Al Mi'yar: Jurnal Ilmiah Pembelajaran Bahasa Arab dan Kebahasaaraban 2, no. 2 (July 27, 2019): 149-64, https://doi.org/10.35931/am.v2i2.119. 
Namun hal ini masih bisa diatasi jika dosen atau salah satu mahasiswa menggunakan fitur record untuk merekam semua aktifitas perkuliahan dari awal sampai akhir dan mendistribusikan hasil rekaman ke seluruh mahasiswa.

2. Pembatasan Media

Media gratis tentunya memiliki beberapa batasan dalam penggunaannya. Perkuliahan Maharah Kalam dengan menggunakan media Zoom Cloud Meeting gratisan hanya dapat dilaksanakan selama 40 menit. Jika sudah mencapai 40 menit, notifikasi akan muncul di seluruh layar pengguna dan layar Zoom Cloud Meeting secara otomatis akan berhenti.

Fitur record hanya tersedia apabila dosen atau mahasiswa memanfaatkan media Zoom Cloud Meeting di laptop atau PC. Maka sangat disarankan bagi dosen pengampu mata kuliah sekaligus sebagai server utama para partisipan pada perkuliahan untuk tidak menggunakan smart phone melainkan menggunakan laptop atau PC.

\section{Penutup}

Dari penelitian ini peneliti menyimpulkan beberapa tahapan yang digunakan oleh dosen dalam penyelenggaraan perkuliahan Maharah Kalam secara daring (online) dengan menggunakan media Zoom Cloud Meeting, yakni: (1) PraPerkuliahan, dosen memberikan informasi kepada mahasiswa mengenai tema yang digunakan pada pelaksanaan perkuliahan Maharah Kalam serta edukasi seputar tata cara penggunaan media Zoom Cloud Meeting. (2) Pelaksanaan Perkuliahaan, dosen menggunakan metode storytelling dan mubadatsah dalam pelaksanaan perkuliahan Mabarah Kalam menggunakan media Zoom Cloud Meeting. dosen juga memanfaatkan fitur record untuk merekam segala aktivitas yang terjadi selama perkuliahan berlangsung dan fitur chat untuk membantu jika beberapa mahasiswa mengalami kerusakan speaker. (3) Evaluasi Perkuliahan, penilaian hasil perkuliahan Maharah Kalam disesuaikan dengan beberapa aspek seperti pelafalan/suara, tata bahasa, pemilihan kosakata, kelancaran, dan kemampuan merespon pertanyaan dengan baik. Dosen juga memanfaatkan fitur Whiteboard yang tersedia di media Zoom Cloud Meeting untuk membantu jalannya proses evaluasi hasil. Tentunya, sebuah media yang disediakan secara gratis tidak akan lepas dari berbagai macam kekurangan. beberapa fitur tidak akan berfungsi jika hanya mengandalkan aplikasi gratisan. Namun, terlepas dari segala kekurangan yang ada media Zoom Cloud Meeting ini terbukti dapat digunakan sebagai media alternatif dan representatif dalam pelaksanaan perkuliahan yang mengharuskan adanya aktifitas face to face secara langsung seperti mata kuliah Maharah Kalam. Peneliti berharap bahwa hasil penelitian ini dapat memberikan wawasan dan juga solusi dari berbagai macam masalah yang dialami para dosen untuk melaksanakan perkuliahan secara daring (online) di tengah musibah wabah corona 
virus disease dan juga musibah lainnya seperti fenomena kabut asap yang terjadi secara tahunan di beberapa Provinsi di Negara Indonesia.

\section{Bibliografi}

Albantani, Azkia Muharom. "Social Media as Alternative Media for Arabic Teaching in Digital Era." ALSINATUNA 4, no. 2 (June 25, 2019): 148-61. https://doi.org/10.28918/alsinatuna.v4i2.2043.

Archibald, Mandy M., Rachel C. Ambagtsheer, Mavourneen G. Casey, and Michael Lawless. "Using Zoom Video conferencing for Qualitative Data Collection: Perceptions and Experiences of Researchers and Participants:" International Journal of Qualitative Methods, September 11, 2019. https://doi.org/10.1177/1609406919874596.

Aslamiyah, Tsuwaybah Al, Punaji Setyosari, and Henry Praherdhiono. "Blended Learning Dan Kemandirian Belajar Mahasiswa Teknologi Pendidikan.” Jurnal Kajian Teknologi Pendidikan 2, no. 2 (June 22, 2019): 109-14. https://doi.org/10.17977/um038v2i22019p109.

Azmi, Minatul, and Maulida Puspita. "Metode Storytelling Sebagai Solusi Pembelajaran Maharah Kalam di PKPBA UIN Malang” 3, no. 0 (2019): 69-86.

Darr, Amber Y., Samantha Erickson, Tanya Devine, and ThuyTien Tran. 'Design and Students' Perceptions of a Virtually Facilitated Outpatient Pharmacy Practice Laboratory Course." Currents in Pharmacy Teaching and Learning 11, no. 7 (July 1, 2019): 729-35. https://doi.org/10.1016/j.cptl.2019.03.012.

Emda, Amna. "Kedudukan Motivasi Belajar Siswa dalam Pembelajaran." Lantanida Journal 5, no. 2 (March 15, 2018): 172-82. https://doi.org/10.22373/lj.v5i2.2838.

Ghani", Mohammad Taufiq Abdul. "The Effectiveness of Using Website in Learning Arabic Language for The Purpose of Tourism: A Case Study among Students at College Poly-Tech." International Conference on ELearning, 2015, 9.

Haniah, Haniah. "Pemanfaatan Teknologi Informasi Dalam Mengatasi Masalah Belajar Bahasa Arab.” Al-Ta'rib: Jurnal Ilmiah Program Studi Pendidikan Bahasa Arab IAIN Palangka Raya 2, no. 1 (June 1, 2014). https://doi.org/10.23971/altarib.v2i1.588.

Hiong, Siaw Nyuk, Yahya Bin Sedik, Agatha Anak Francis Umbit, Lim Boon Yann, Lai Kim Leong, and Anis Alisya Abdullah. "A SWOT-Thematic Analysis of Blended Learning Practices at Institute of Teacher Education Malaysia." DEStech Transactions on Social Science, Education and 
Human Science 0, no. ICEdDE (2019). https://doi.org/10.12783/dtssehs/ICEdDE2019/33702.

Ilmiani, Aulia Mustika, Ahmadi Ahmadi, Nur Fuadi Rahman, and Yulia Rahmah. "Multimedia Interaktif Untuk Mengatasi Problematika Pembelajaran Bahasa Arab." Al-Ta'rib: Jurnal Ilmiah Program Studi Pendidikan Bahasa Arab LAIN Palangka Raya 8, no. 1 (June 24, 2020): 17 32. https://doi.org/10.23971/altarib.v8i1.1902.

Serambi Indonesia. "Instruksi Presiden Jokowi: Saatnya Kerja dari Rumah, Belajar dari Rumah, Ibadah di Rumah.” Accessed November 11, 2020. https://aceh.tribunnews.com/2020/03/15/instruksi-presiden-jokowisaatnya-kerja-dari-rumah-belajar-dari-rumah-ibadah-di-rumah.

Iswanto, Rahmat. "Pembelajaran Bahasa Arab dengan Pemanfaatan Teknologi." Arabiyatuna: Jurnal Bahasa Arab 1, no. 2 (December 29, 2017): 139-52. https://doi.org/10.29240/jba.v1i2.286.

Latief, Karwati Putu. "Arti Lockdown, Social Distancing dan Istilah Populer Seputar Virus Corona.” Harapan Rakyat Online (blog), March 15, 2020. https://www.harapanrakyat.com/2020/03/arti-lockdown-socialdistancing-dan-istilah-populer-seputar-virus-corona/.

Linur, Rahmat, and Mahfuz Rizqi Mubarak. "Facebook Sebagai Alternatif Media Pengembangan Mahara Kitabah." Jurnal Naskbi: Jurnal Kajian Pendidikan Dan Babasa Arab 2, no. 1 (April 27, 2020): 8-18. https://doi.org/10.47435/naskhi.v2i1.154.

Liputan6.com. "Antisipasi Covid-19, Dikti Minta Kampus Selenggarakan Kuliah Jarak Jauh.” liputan6.com, March 14, 2020. https://www.liputan6.com/news/read/4201640/antisipasi-covid-19dikti-minta-kampus-selenggarakan-kuliah-jarak-jauh.

Mubarak, Mahfuz Rizqi, Nurul Wahdah, Aulia Mustika Ilmiani, and Hamidah Hamidah. "Penggunaan Vlog Dalam Pembelajaran Mahārah Kalām." Al Miyar: Jurnal Ilmiah Pembelajaran Bahasa Arab dan Kebahasaaraban 3, no. 1 (April 4, 2020): 109-26. https://doi.org/10.35931/am.v3i1.209.

Muna, Wa Muna Wa. "Efektifitas Metode Muhadatsah Terhadap Penguasaan Bahasa Arab Mahasiswa STAIN Kendari." Shautut Tarbiyab 16, no. 1 (May 1, 2010): 108-19. https://doi.org/10.31332/str.v16i1.122.

Rozak, Abd, and Azkia Muharom Albantani. "Desain Perkuliahan Bahasa Arab melalui Google Classroom." Arabiyat: Jurnal Pendidikan Bahasa Arab dan Kebahasaaraban 5, no. 1 (June 3, 2018): 83-102. https://doi.org/10.15408/a.v5i1.7481. 
Sa diyah, Halimatus. "Upaya Menumbuhkan Self-Confidence Berbicara Bahasa Arab Mahasiswa Melalui Grup Whatsapp." Al Mi'yar: Jurnal Ilmiah Pembelajaran Babasa Arab dan Kebahasaaraban 2, no. 2 (July 27, 2019): 149_ 64. https://doi.org/10.35931/am.v2i2.119.

Sebayang, Rehia. "Pasien Covid-19 RI 117 Orang, Jokowi Bicara Soal Lockdown." news. Accessed November 11, 2020. https://www.cnbcindonesia.com/news/20200315154622-4144982/pasien-covid-19-ri-117-orang-jokowi-bicara-soal-lockdown.

Sutterlin, Jane. "Learning Is Social with Zoom Video Conferencing in Your Classroom." ELearn 2018, no. 12 (December 28, 2018): 5. https://doi.org/10.1145/3302261.3236697.

“Zoom Meetings - Zoom.” Accessed October 18, 2020. https://zoom.us/meetings. 